\title{
The Development of an Ingenious Circuit Based on Chemo-Edutainment Learning
}

\author{
Sri Adelila Sari ${ }^{1}$, Yuni Sri Rezeki ${ }^{2}$
}

\begin{tabular}{l} 
ARTICLE INFO \\
\hline Article History: \\
Received 29.08.2018 \\
Received in revised form \\
02.10.2018 \\
Accepted \\
Available online 01.01.2019
\end{tabular}

\begin{abstract}
One way to solve the problem of chemistry learning is that teachers are expected to have methods, models of teaching and learning, as well as learning media that can choose according to the subject concepts to be conveyed. This research was aimed to develop a learning media called as ingenious circuit, and to describe the activity also users' feedback on the developed media. The type of research was research and development ( $R \& D$ ). While the used design of development was ADDIE (Analysis, Design, Development, Implementation, and Evaluation) using qualitative methods. The research was conducted in senior high school named SMAN 1 Krueng Barona Jaya in class XI MIA 2 with a number of 20 students. The instruments used to collect the data were a sheet for media validation, questionnaires to measure the response, and the observation sheet to measure student activity during use the developed media. After the ingenious circuit was developed with the phase of ADDIE, the validation results showed that a viable ingenious circuit up to 100 percent on aspects of the format. While the visual aspect, the feasibility of achieving 90.62 percent. In addition, the circuit was also tested for eligibility based on the aspect of clarity in the presentation of the question and the results was found to reach 100 percent, as well as on aspects of functioning or quality of 87.5 percent. This study also found that the response of the students after they used the media, including the highly positive, as much as 90.00 percent. As well as with teachers, the responses were in very good condition, which reached 89.29 percent. In addition, the student activity test results when they use this developed circuit was considered very active, with an average percentage score of 80.57 . Based on the overall results of the study, it can be concluded that a series of ingenious circuit could be developed with ADDIE model and feasible to implement in the learning process of colloids. In addition, the responses of students and teachers those who used the circuit were also very positive, especially the students more active in the learning process of colloids.
\end{abstract}

C 2018 IJERE. All rights reserved

Keywords:

Circuit ingenious, chemo-edutainment, colloid, activity, and response

\section{INTRODUCTION}

Chemistry is a branch of science that requires experimental, reasoning, and analysis to understand the material. During this time, we know that the views of the students towards learning chemistry is very scary and difficult to understand. One of the problems faced in education today is the weakness of the learning process. The learning process successful if during the learning activities of students showed a high learning activities and actively looks both physically and mentally. On the subjects of chemistry in high school, less effective learning process can increase the number of students' lack of interest and motivation for learning chemistry. The students who lack motivation appears among others, lack of learning, interaction in the learning process and the preparation of students to learn (Samuel, 2012).

The success of the learning objectives determined by many factors, among which are the factors teachers in implementing the learning process, because it can directly affect the teachers, foster and improve intelligence and skills of students. To solve the above problems and to achieve the maximum level, the teacher's role is very important and teachers are expected to have a method/model of teaching and learning models that can either choose appropriate and in accordance with the concepts of the subjects that will be delivered. Teachers must be smart to develop an attractive media that the colloidal material is no longer considered a boring material. Learning fun and not boring can be implemented by adopting some simple games (Taqwima, et.al., 2013). One simple game that can entertain students is smart circuit. The circuit media cleverly create higher student enthusiasm for new media in learning chemistry by utilizing the students' interest in the game.

\footnotetext{
${ }^{1}$ Corresponding e-mail: sriadelilasari@unimed.ac.id, orcid.org/0000-0002-4444-6317 State University of Medan1 , Syiah Kuala University, Banda Aceh ${ }^{2}$
} 
One example of creativity that can be done, for example choosing a relatively large media involving active student learning and create innovations that take the fun to be able to support the success of learners. By using the appropriate media will assist in the achievement of learning outcomes in accordance with the purpose of the material itself (Baharudin, 2010). At junior high Daar El-Qalam Tangerang, circuits on mathematics could increase the concentration of students in full so that the material being taught by teachers can be understood by students with ease (Switri, 2014). It revealed that the game uses a smart circuit method is one method of game that can improve student participation and educational value of the games. According to Priatmoko, et.al., (2012), learning by utilizing smart circuit as the effect of the chemoedutainment media on the subject of student learning outcomes in acid and alkaline solution. Chemistry is a subject of universal interest in human development with regards to the utility of its knowledge in reallife situations likely to be faced by many of the students some day. The teacher is thus the key factor in regular diagnosis, correction and prevention of Chemistry students' weaknesses in order to enhance their academic achievement (Samuel, 2012).

\section{Situation of the Problem}

A senior high school called SMA Negeri 1 Krueng Barona Jaya which is a pilot school in Great Aceh asked to learn better than students in other schools in Aceh Besar. Despite being a pilot school, there are still problems in this school because there are many grades of students who have not reached the minimum value criteria of completeness, which has been determined in the school 75. Based on initial observations with a high school chemistry teacher 1 Krueng Barona Jaya, he said that students still passive in the learning process, because of the lack of independence of students in learning. Based on the data completeness, percentage of daily test results of students in the 2013/2014 academic year on colloidal material which was 52.63 percent. While the national exam results data from the Ministry of National Education in senior high school at Krueng Barona Jaya in the academic year 2013/2014 in terms of completeness colloidal, scores at 56, 10 percent (Kemdikbud, 2014)

\section{Aim of the Study}

From the above description, researcher was interested in designing circuits' media cleverly using instructional design model. There are several models of instructional design as a model ASSURE, ADDIE models, models of Dick \& Carey, Jerold E. Kemp models, as well as models of Smith and Ragan. However, in this study, the researchers chose to use ADDIE model of instructional design. This was because the stages of the electoral model of instructional design that is simple and easy to learn. The purpose of this study was to develop of ingenious circuit media, to describe the student activities towards developed circuit, and the response from students and teachers to the developed ingenious circuit. This research was expected to have a positive impact on the implementation of the learning process carried out by the teacher in the classroom.

\section{METHOD}

This type of research was the study design using the model ADDIE. One of the functions of the model ADDIE, which serve as guidelines in building infrastructure tools and training programs were effective, dynamic and performance training to support itself. This model used a five-stage development as follows:

Analysis is the process of defining what will be learned by learners, to conduct a needs analysis, identify problems, and perform analytical tasks. The design, known as the draft design stage (blueprint). The development is a process of realizing the design is made into reality. Implementation is a concrete step to implement a learning system that is created. Evaluation is the process to see if the system is being built learning succeed, according to initial expectations or not.

The ingenious circuit was the result of the development of the game of snakes and ladders that were familiar to the students. The series of ingenious was the value of the game media education, productive, fun, and was expected to benefit more in learning (Switri, 2014). The ingenious game circuit was a modified version of the game of monopoly that was familiar to the students. The series was a smart game media educational value, productive, and fun, which is expected to benefit more in learning (Priatmoko, et.al., 2012). The approach used in this study was a qualitative approach, the approach used to examine the 
condition of natural objects (Arikunto, 2011). The diversity of this study was to describe the systematic descriptive facts and proper subject characteristics (Sukardi, 2003).

This study had been conducted in senior high school called SMA Negeri 1 Krueng Barona Jaya, Krueng Barona Jaya, Great Aceh, Indonesia. Subjects in this study were 20 (twenty) students of class XI IA-2 SMA Negeri 1 Krueng Barona Jaya, Aceh Besar. They were 11 (eleven) girls, and 9 (nine) boys. All of them were Acehnese. The instruments used to collect the data were a sheet for media validation, questionnaires to measure the response, and observation sheet to measure student activity during use the developed media. Validity was determined based on the assessment of two experts in chemistry and media.

\section{Material}

The instruments used to collect data were:

Questionnaire sheet

The disseminated instrument contained questions compiled according to the criteria for obtaining student response information during the product trial and teacher response to Ingenious Circuit learning media that had been developed by researchers.

1. Feasibility assessment sheet

This feasibility assessment sheet was reviewed by 2 validators namely Chemistry Education lecturers at Syiah Kuala University, then qualitative analysis so that the validity of Ingenious Circuit learning media could be concluded.

2. Observation sheet

Observation sheet was an evaluation tool that was widely used to assess individual behavior or the process of occurring an activity that can be observed (Sudijono, 2011). Observation sheets were used to view student activities during the research using Ingenious Circuit media starting from the beginning to the end of the study.

3. Instrument Validation Test

Instrument validation was carried out on the teacher response questionnaire sheet, student response questionnaire sheet, and media validation sheet. One of the instrument requirements can be used if it has been validated or declared valid. To get valid data, instruments or tools to evaluate it must be valid. Validity is determined based on the assessment of two expert validators in the field of chemistry and media. Each validator provides an assessment of the questions given. The questions included were media format aspect, visualization aspect, and components of media clarity in aspects of presentation of questions.

\section{Data Analyses}

\section{Media Feasibility Sheet}

The data was processed using descriptive analysis with regard to the relevant aspects of instructional media design. Improved terms of media format, visualization, and presentation of concepts. The criteria for evaluating media feasibility are expressed in percentages calculated using the formula as in equation (3.1)

Presentation of feasibility value $=($ score obtained $) /($ maximum score $) \times 100 \%$

To provide a percentage score, the media feasibility assessment can be seen in Table 1 .

Table 1. Scores of Feasibility Media Assessment

\begin{tabular}{cll}
\hline Number & Percentage of Score (\%) & Categorization \\
\hline 1 & $10-20$ & $\begin{array}{l}\text { Very } \\
\text { inappropriate }\end{array}$ \\
\hline 2 & $21-40$ & Not feasible \\
\hline 3 & $41-60$ & Enough \\
\hline 4 & $61-80$ & Decent \\
\hline
\end{tabular}


Sari,A.S. \& Rezeki,S.Y. (2019).The development of an ingenious circuit based on chemo-edutainment learning. International Journal of Educational Research Review,4(1),15-25.

$5 \quad$ 81-100 Very decent

(Source: Arikunto and Jabar, 2010)

\section{Student and Teacher Responses}

Student and teacher response data were obtained from the results of filling out the student and teacher response questionnaires. To analyze the data obtained from the questionnaire, the frequency distribution formula is used as equation (3.2) (Sudjana, 2010) as follows:

$$
\mathrm{P}=\mathrm{f} / \mathrm{N} X 100 \%
$$

Information:

$\mathrm{P}=$ Percentage

$\mathrm{f}=$ Frequency

$\mathrm{N}=$ Number of Respondents

To provide a questionnaire score on the average value of the frequency distribution results calculated based on alternative answers to the sample can be seen in Table 2 .

Table 2. Assessment of Scores Questionnaire

\begin{tabular}{cll}
\hline Number & Percentage of Score (\%) & Categorization \\
\hline 1 & $80-100$ & Very good \\
\hline 2 & $66-79$ & Good \\
\hline 3 & $56-65$ & Enough \\
\hline 4 & $46-55$ & Less \\
\hline 5 & $0-45$ & Failed \\
\hline
\end{tabular}

(Source: Sudijono, 2011)

\section{Student activity}

Data about student activities collected from observation sheets during research using intelligently designed circuits were analyzed using percentage formulas as in equation (3.3)

$$
\text { Value }=(\text { total score }) /(\text { maximum score }) \times 100 \%
$$

Data from observing student activities during the research activities were analyzed using descriptive statistics through scores. To provide an activeness score can be seen in Table 3.

Table 3. Activity Assessment Scores

\begin{tabular}{cll}
\hline Number & Percentage of Score (\%) & Categorization \\
\hline 1 & $80-100$ & Very good \\
\hline 2 & $66-79$ & Good \\
\hline 3 & $56-65$ & Enough \\
\hline 4 & $46-55$ & Less \\
\hline 5 & $0-45$ & Very bad \\
\hline
\end{tabular}

(Source: Arikunto, 2011)

\section{FINDINGS}

A. The Development of an Ingenious Circuit

Analysis Phase was conducted based on a needs analysis and identify problems that happened. It was decided to develop a learning media as an ingenious circuit. This product was chosen because the game cleverly circuit was a modified a media monopoly and snakes and ladders. This is familiar to the students, so it will facilitate students to play. It is as expressed by Sadiman, et.al., (2008), which stated that the cause of the person's choosing media was due to already felt familiar with the media. 
In addition, according to a study done by Priatmoko, et.al., (2012), the ingenious circuitry media was a media game that was worth educative, productive, and fun, which was expected to benefit more in learning. The development of the game media to broaden the students due to lack of instructional media for chemical material that is only a guide, so that students quickly feel bored to understand the material.

Design Phase. At this stage, the design of the product was made, the product produced in the form of chemical instructional ingenious circuit of colloids. Colloidal material was one of learning materials chemistry at the high school level classes XI $2^{\text {nd }}$ semester circuits Games ingenious in design by modifying the monopoly and snakes and ladders game that we had been know daily life. This learning media was designed so that attract students to enjoyable learning. At this stage, designed some of the components required in the learning media such as media board, pawns to play, and a set of game cards (card proprietary questions, trap cards and card points). The preliminary design of ingenious circuit board games can be seen in Fig.1.

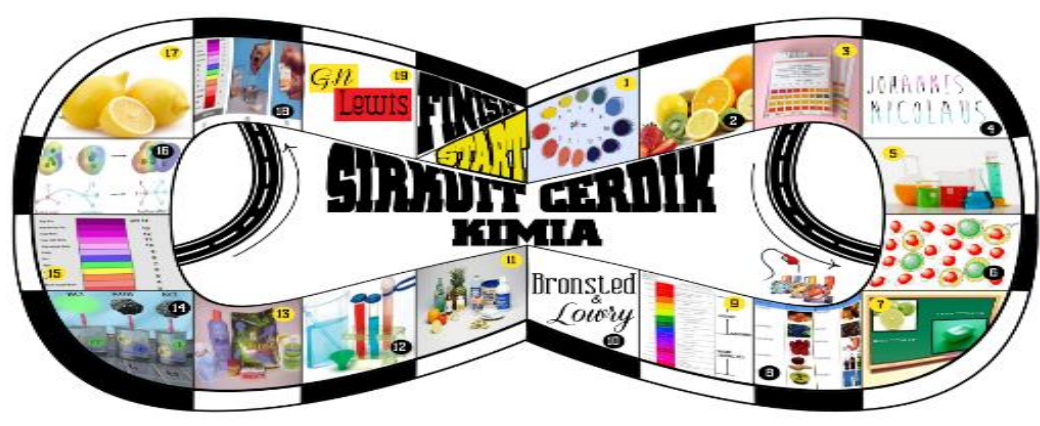

Figure 1. The preliminary design of ingenious circuit board game.

Development Phase. The ingenious circuit was developed in accordance with the purpose of learning, as described at the design phase. The components to be made were a board game, a pawn to play, and a set of game cards like card question, trap cards and point cards, as describe below:

1) The Ingenious Circuit based on Chemo-Edutainment Learning. This was a monopoly game which has been modified from game of snakes and ladders. The circuit was developed from a rectangular board with a size of $80 \times 60 \mathrm{~cm}$. On the board, there were 16 plots, which consisted of: swath of stars, and 15 pieces of hide-question cards. The ingenious circuit board can be seen in Fig.2.

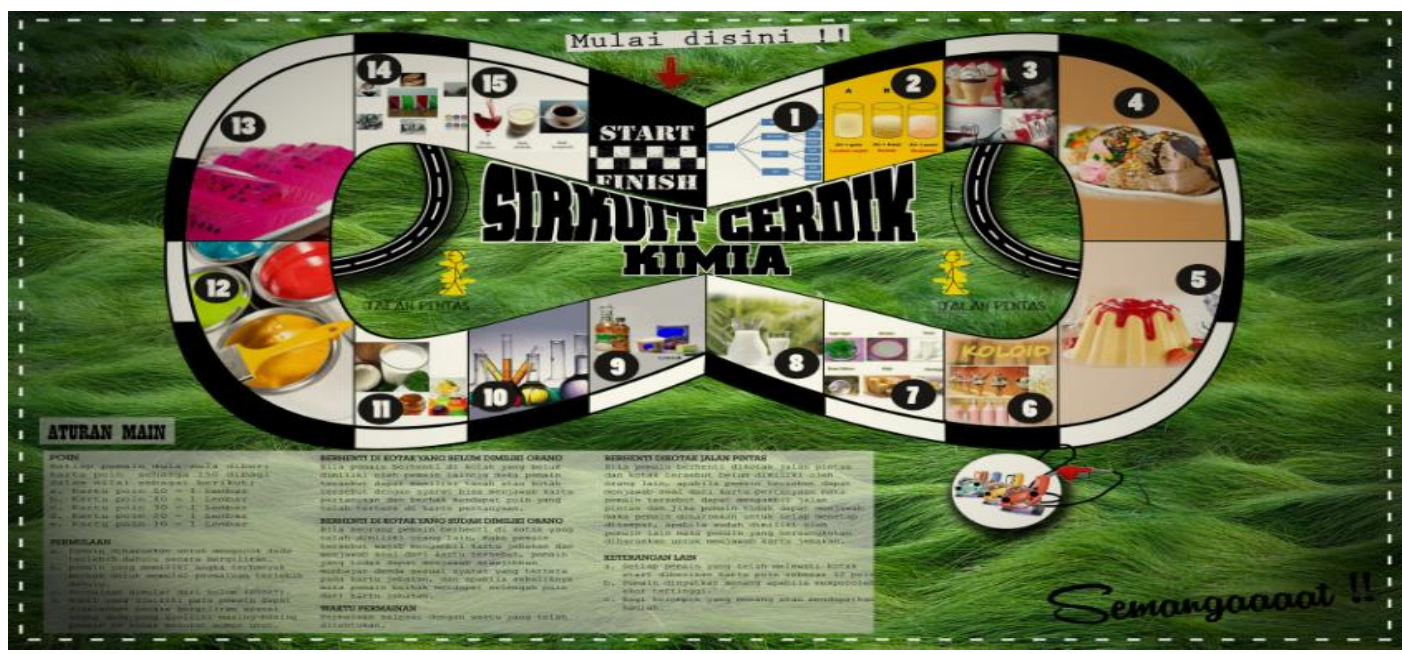


Figure 2. The Game Board of Ingenious Circuit

This game in such a way that the design was easy and practical to carry anywhere to play. This was consistent with that expressed by Arsyad [8], which stated that one of the criteria that should be ordered in the selection of media was practical, flexible, and survive. This game was equipped with a set of playing cards. The set of cards was consisted of a proprietary question cards, trap cards, and point cards.

\section{Property Right Question Cards}

The property right question cards were contained 15 (fifteen) questions relating to the colloidal material. Thus children could learn about the colloids. This question cards shown during his turn, when the shuffle played and stopped at one patch of material, then the group would get a card and the question of the group members shall discuss to answer the questions referred to the question cards. If the group can answer the questions then the group got the points that already exist on the card. The example of property right question cards can be seen in Fig. 3.
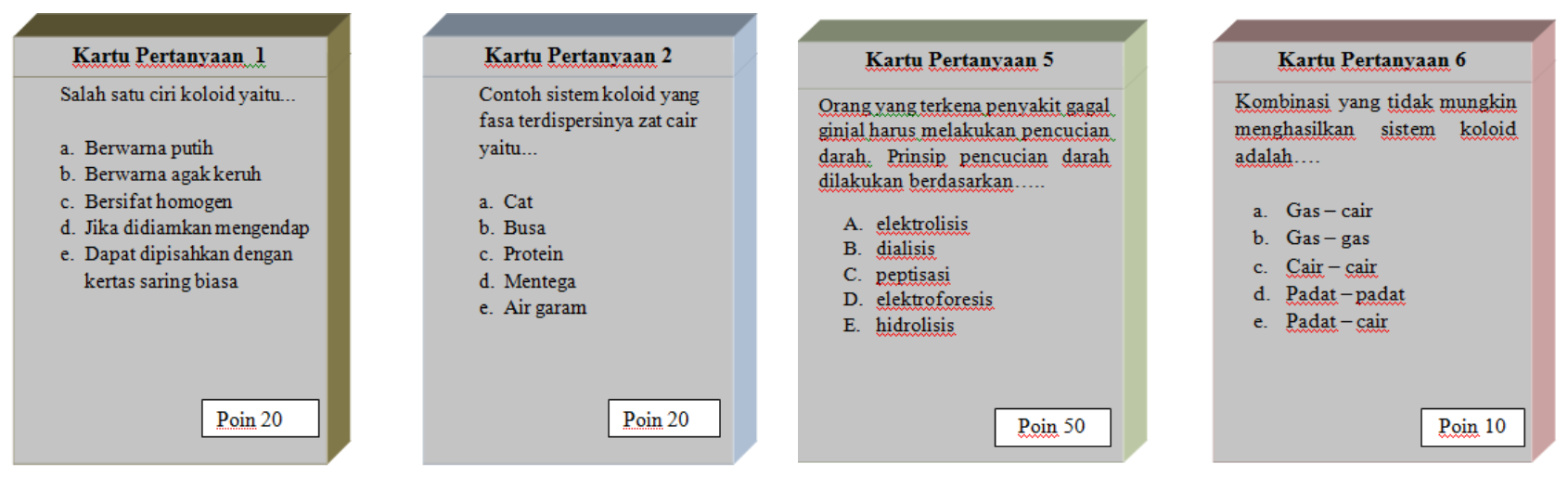

Figure 3. Question Cards

\section{Trap Cards}

Trap card was a replacement of the card, where tricky question was taken at one point stopping place or the ground was already owned by another group. This card was designed to add excitement to the game, so the game was not too monotonous. This card was consisted of 15 pieces of cards and shown in Fig. 4.
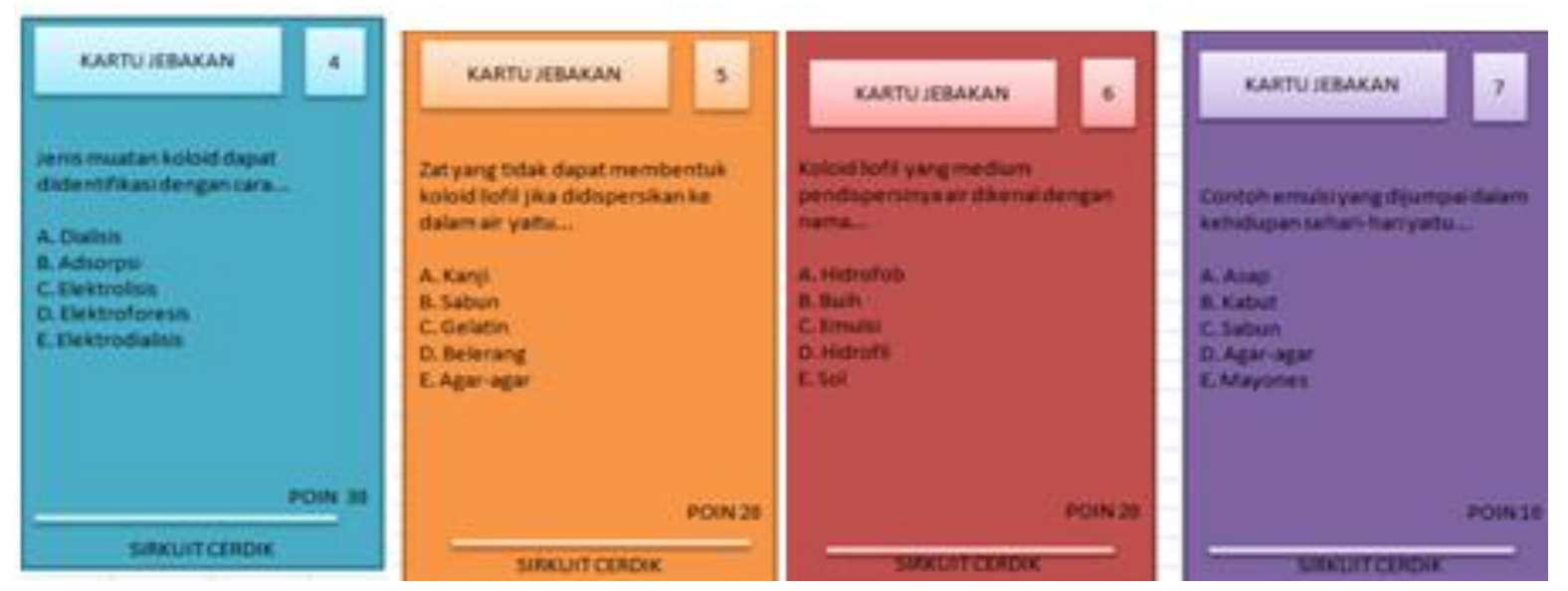

Figure 3. Trap Cards 
Sari,A.S. \& Rezeki,S.Y. (2019).The development of an ingenious circuit based on chemo-edutainment learning. International Journal of Educational Research Review,4(1),15-25.

\section{Point Cards}

The point cards as shown in Fig. 5 were the cards which replacement of fake money as commonly found in a monopoly game. In addition the point cards would be get when students were able to answer the questions from the question cards and trap cards. When the student had passed the star box, the point cards would be received.
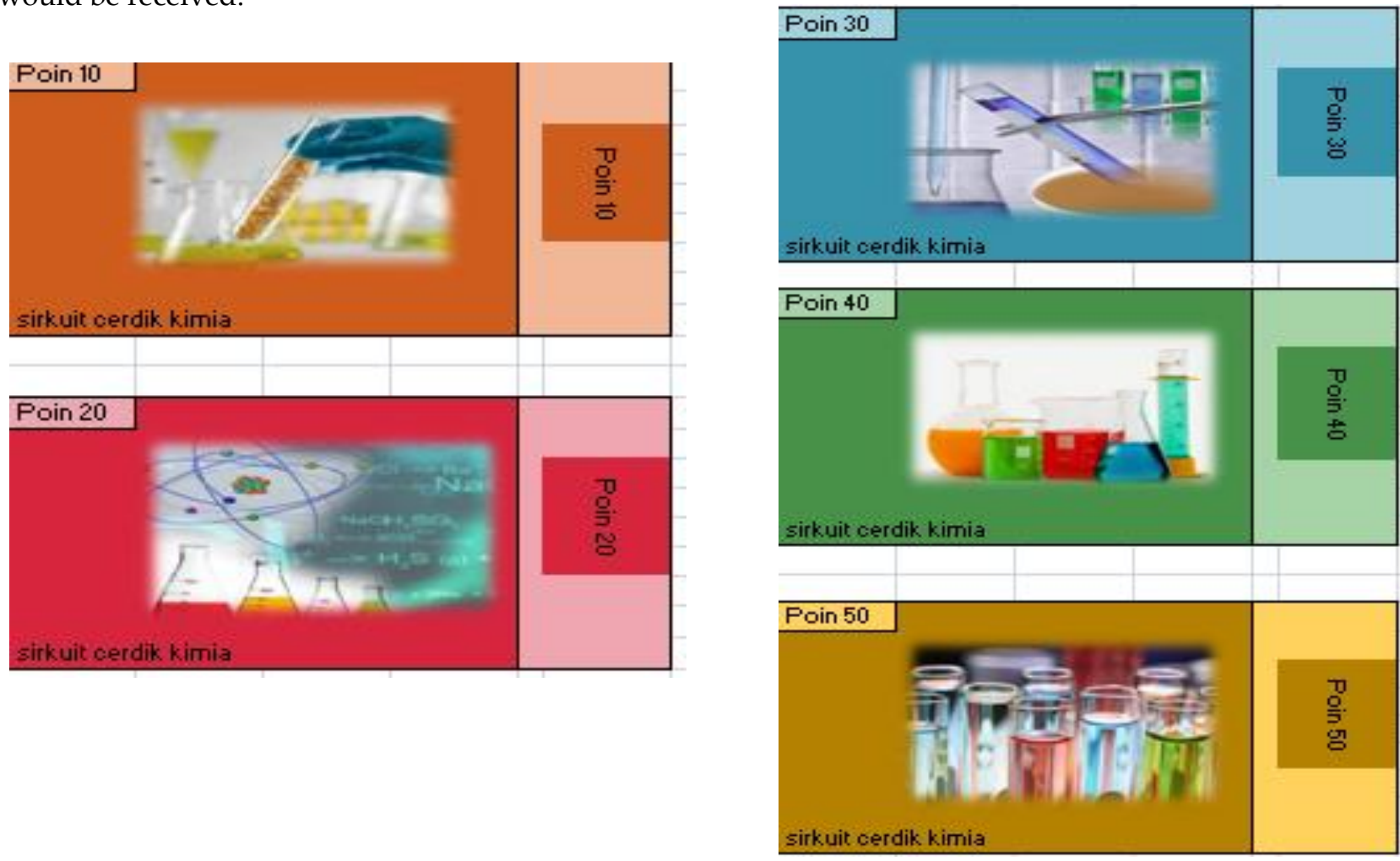

Figure 5. Point Cards

The point cards were consisted of 5 (five) points, i.e., 10 to 50 points. This cards were also have some pictures related to chemistry. Each player would initially be distributed point cards amounted to 150 points and would go back to get points if it could be answered the questions in the question cards and trap cards, players will also earn points by 10 points when it passed the star box.

\section{The Pawn}

This game came with a pawn in the form of toy car with four colors: red, yellow, green and blue. The colors were distinguished by the group in order to easier to distinguish between one groups against another. Where one pawn could be divided into 4-5 students, which could be played in turns. The cars that were used as pawns can be seen in Fig. 6 .

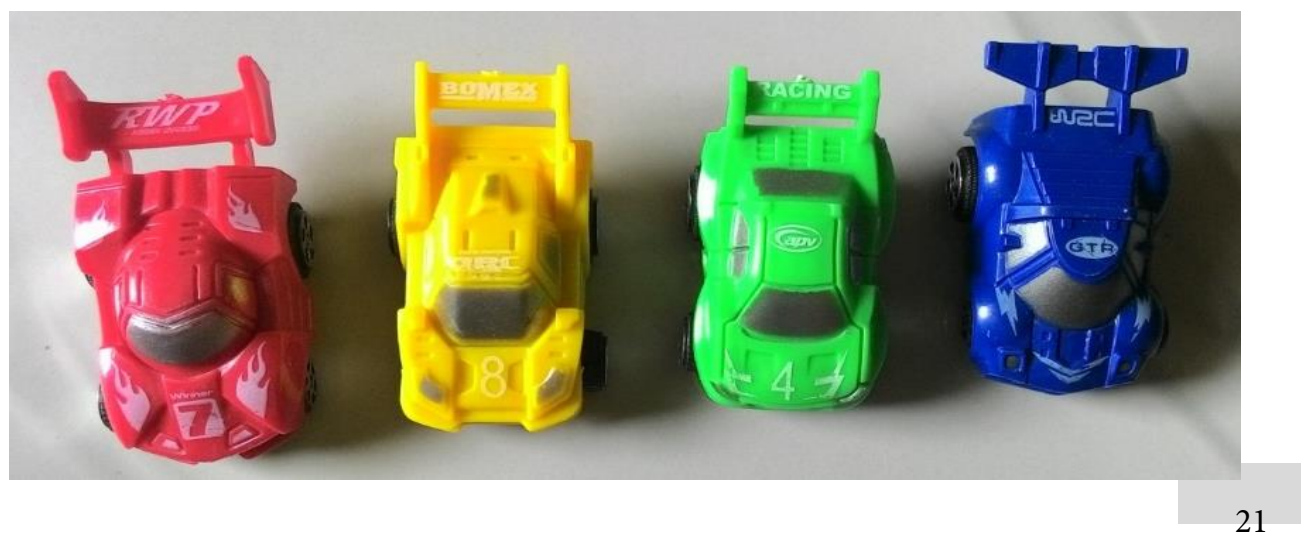


Figure 4. The Pawns of The Ingenious Circuit Game

\section{Dice and Shuffle}

This game provided 1 (one) dice and 1 (one) shuffle. The dice were slightly larger than the dice which used in monopoly game. Fig. 7 shows dice and shuffle used to play.

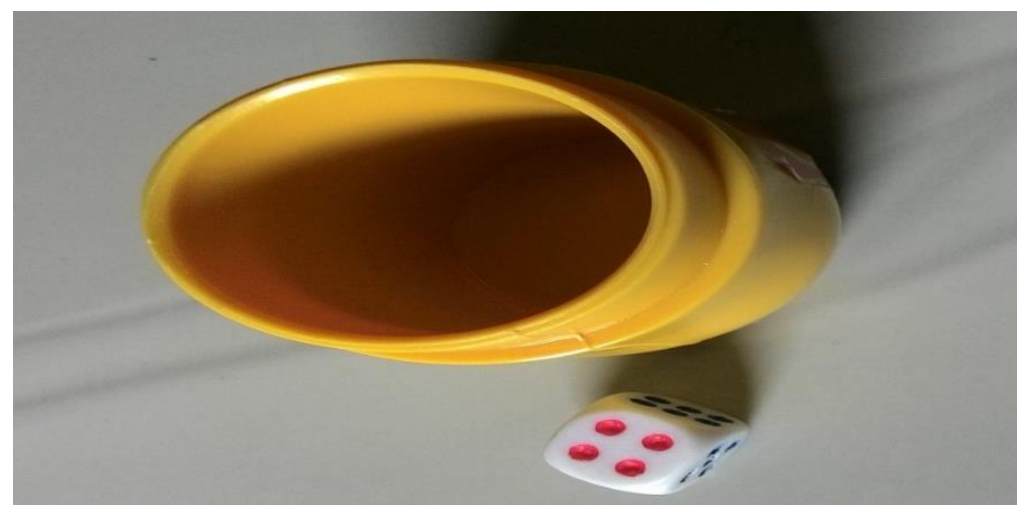

Figure 5. Dice and Shuffle

\section{RESULTS, DISCUSSION, AND SUGGESTIONS}

After the ingenious circuit was developed, then the circuit was validated to determine whether it was feasible to use or not. The circuit media was validated by two validators. The results showed that the average percentage of each media aspects of eligibility, such as: format, visualization, and clarity of presentation aspects were found to be 100; 90.62; and 100 percent, respectively. While the average percentage of eligibility for all aspects was found to be 96.87 percent. Based on the results obtained, it can be concluded that the developed ingenious circuit based on chemo-edutainment learning was very feasible to use.

\section{Implementation (Trial) Phase}

Mukhlishin, et.al., (2013), stated that the purpose of the implementation was a step to check the feasibility of the learning product. The validation of product development include expert test material, media and lecturers in order to obtain feedback to improve the initial prototype. It also has been expressed by Susanta, et.al., (2014), that the implementation was a step in the application of learning. The implementation of products thing to note was validated by media experts, after it had conducted a trial to assess the feasibility of a medium that has been developed.

The implementation was conducted in SMAN 1 Krueng Barona Jaya, Great Aceh on 2015 year in class XI MIA 2. The class was chosen based on some suggestions from their chemistry teacher. Test phase was conducted to determine how the student activity after using ingenious circuitry media. This study was supported by Ekmekci and Gulacar, (2015), which presented a case study comparing the effectiveness of computer-based versus hands-on instructional activity on learning electric circuits. The results showed that both approaches significantly improved pre-service mathematics and science teachers' learning of electric circuits. The two types of instructional activities did not significantly differ from each other in terms of learning gains. However, hands-on activity provided ample opportunities for group interaction as well as task-related discussions. This study shows that both computer-based and hands-on activities can be effective when utilized in the right classroom environment.

\section{Evaluation Phase}


The evaluation phase was the last stage of the ingenious circuit development. At this stage, the scoring of learning that has been done using ingenious circuit game was evaluated. According to Pribadi, (2009), the evaluation could be defined as a process to provide the student learning outcomes. At this stage, the feasibility assessment of circuit media, student responses, the response of teachers, and the results of student activity were evaluated. The purpose of this evaluation was to determine whether the developed ingenious circuits was feasible or not for use in learning chemistry with colloidal materials.

\section{Activities of Students}

Students' activities were observed using observation sheet. This observation sheets were filled out by four observers, who were divided into 5 (five) groups. The observation of activities was done from start to end of the class. Based on observation of student activities, it has been showed that students were actively participated when learning takes place. Thus, the use of ingenious circuit based on chemo-edutainment could encouraged students to be very active. The activities of students were found to be average of 69.47 percent in the first meeting and 80.57 percent in the second meeting. It also agreed with Switri, (2014) who found that the observations of the students' activities has achieved the expected success indicators. The activities tested in this study did appear to improve students' understanding of circuits significantly. This finding was supported by the prior research that there were studies in the literature showing the effectiveness in students' science learning Valdez, et.al., (2013). On the other hand, the motivation of students and the interaction among them were increased. The students seemed more engaged in the tasks. They were more engaged in group communication and exchanged ideas more effectively. Students' thinking also became more visible by the instructor and researchers (Ekmekcy and Ayar, 2012).

\section{User's responses}

Students and teachers' responses were measured against the media by giving questionnaires. The function of the provision of this questionnaire was to get the feedback on the trials conducted on ingenious circuit. Students those who completed a questionnaire of response to the media was students who has been used the media, while teachers were 2 (two) chemistry teachers in study school. The questionnaires were given to students of class XI MIA 2 at the end of the meeting. Students' responses were found to be positive with the average of 90 percent. In addition to the positive response was given, the teachers were also gave the excellent responses to the ingenious circuit with the acquisition of 89.29 percent which categorized very well. The limitation of this study was not to describe the learning outcomes of students.

The results of this study were in line with Cahyana, et.al., (2017) those who found that mobile game based learning was feasible to be used as chemistry learning media which was practical, fun, interesting. It also could be used anywhere, in accordance with facilities owned by learners. In addition, Kristen, et.al., (2017) found that chemistry students, in today's secondary education schools, need instruction that fosters active learning and student-peer engagement, while building 21st century workforce skills. In other works, Sari, et.al., (2012) developed android-based educational game on chemically oriented colloidal materials. They found that student's chemical literacy were increased by using this game. The usage of games in chemistry classroom was proven to be an excellent way to motivate students, to provide active engagement and discussion among students and to develop skills to solve problems (Stojanovska \& Velevska, 2018). Leala, et.al. (2017) concluded that the serious game developed showed positive results in learning and motivation demonstrated by the students, regardless of the group analyzed. Thus this study concluded that the game used in learning chemistry was able to provide positive benefits in improving student learning.

Based on the research that has been done, it can be concluded as follows:

1. The ingenious circuit based on chemo-edutainment learning could be developed by ADDIE stages. The circuit has met criteria of very worthy which measured from 4 (four) aspects, i.e., the format of media, the visual aspect, the clarity in the presentation aspects of a matter/ question, and aspects of media functions with percentage of eligibility $100,90.62,100$, and 87.5 percent's, respectively. 
2. The activities of students those who learned using the developed ingenious circuit were found to be 80.57 percent and categorized as very well. It might due to students were enthusiastic highly conducting the circuit trial.

3. The responses of students and teachers on the circuit were found to be very good with average up to 90 percent for students and 89.29 percent's for teachers.

Based on the research that has been done, some suggestions can be given as follows:

1. The ingenious circuit could be used as a new media for chemistry learning, so that it is expected the further study to find the student learning outcomes.

2. Need for further research to measure the level of achievement all of student learning outcomes such as cognitive, affective and psychomotor. And the emphasis on field trials that this media can produce an even better product, like other games.

3. The researchers can develop the other learning media that can attract student interest not only circuits.

4. The ingenious circuits can be developed on any other materials other than colloidal.

\section{REFERENCES}

Arikunto, S. (2011). Dasar-Dasar Evaluasi Pendidikan (Edisi Revisi). Jakarta: PT Bumi Aksara.

Arsyad, A. (2009). Media Pembelajaran. Jakarta: Erlangga.

Baharudin, R. (2010). Keefektifan Media Belajar Berbasis Teknologi Informasi \& Komunikasi. Tadris, 5(1): $112-127$.

Cahyana, U., Paristiowati, M., Savitri, D.A., and Hasyrin, S.N. (2017). Developing and application of mobile game based learning (m-gbl) for high school students performance in chemistry.EURASIA J. Math., Sci Tech. Ed;13(10):7037-7047

Ekmekci, A., \& Ayar, M. C. (2012). Fen bilimleri ogretiminde ogrenci merkezli deneysel vebilgisayar destekli etkinliklerin karsilastirilmasi [Student-centered teaching of science concepts: Affordances of experimental and computer-supported learning environments]. Paper presented at the 21. Ulusal Egitim Bilimleri Kongresi [21st National Conference on Educational Sciences], Marmara University, Istanbul, Turkey.

Ekmekci, A., \& Gulacar, O., (2015). A case study for comparing the effectiveness of a computer simulation and a hands-on activity on learning electric circuits. Eurasia Journal of Mathematics, Science \& Technology Education, 2015, 11(4), 765-775.

Kemdikbud. (2014). Data Pokok Pendidikan dasar dan Menengah. Direktorat jenderal Pendidikan Dasar dan Menengah. Kementerian Pendidikan Kebudayaan. http://dapo.dikdasmen.kemdikbud.go.id/sekolah/259A875B5CF7F9092D9C.

Kristen KB, Malinda WG, Monica D, and Kendra, M. (2017). Pedagogical Methods and Technology Used in Chemistry Secondary Education. Mod Chem appl. Volume 5, Issue 3. Pp. 1-4.

Leala, F., Martinsa, P.C., Torresa, A.F., de Queiroza, J.A., Montevechia, J.A.B. (2017). Learning lean with lego: Developing and evaluating the efficacy of a serious game. Production, 27(spe), e20162227. Pp. 1-15.

Mukhlishin, H., Syahwani, U., dan Edy, T. (2013). Pengembangan Blog sebagai media pembelajaran untuk perolehan belajar konsep kimia karbon di Universitas Muhammadiyah Pontianak. Artikel Penelitian. Fakultas Keguruan dan Ilmu Pendidikan Universitas Tanjungpura, Pontianak.

Priatmoko,S., Saptorini., dan Diniy,H.H. (2012). Penggunaan Media Sirkuit Cerdik Berbasis ChemoEdutainment Dalam Pembelajaran Larutan Asam Basa. Jurnal Pendidikan IPA Indonesia, I(1) : 37-42. 
Sari,A.S. \& Rezeki,S.Y. (2019).The development of an ingenious circuit based on chemo-edutainment learning. International Journal of Educational Research Review,4(1),15-25.

Pribadi, B.A. (2009). Model Desain Sistem Pembelajaran. Jakarta: Dian Rakyat.

Sadiman, A.S., Rahardjo, R., dan Anung, H.,. (2008). Media Pendidikan Pengertian, Pengembangan, dan Pemanfaatannya. Jakarta: PT Raja Grafindo Persada.

Samuel, J.A. (2012). Remediation of students' weakness for enhanced achievement in chemistry. Greener Journal of Educational Research, 2 (4), 095 - 099.

Sukardi. (2003). Metodologi Penelitian Kependidikan. Jakarta. Bumi Aksara.

Susanta, N.A., Sudhita, I.W.R., dan Sudarma, I.K. (2014). Pengembangan Multimedia Interaktif Materi Transportasi Mata Pelajaran Bahasa Indonesia Kelas IV SD Negeri 3 Pegadungan. E-journal Edutech, II(1).

Sari, S., Anjanil, R., Fadida, \& Ramdhani, M.A. (2012). Using android-based educational game for learning colloid material. Journal of Physics: Conf. Series 895. Pp. 1-6.

Sawitri, F. (2014). Peningkatan Hasil Belajar Siswa Kelas III Pada Pembelajaran Matematika Melalui Metode Permainan Sirkuit Pintar Di SDN 28 Payakumbuh. Artikel Penelitian. Fakultas Keguruan Dan Ilmu Pendidikan Universitas Bung Hatta Padang.

Stojanovska, M., and Velevska, B. (2018). Chemistry games in the classroom: A pilot study. Journal of Research in Science, Mathematics and Technology Education. Volume 1, Issue 2, 113 - 142.

Taqwima, A.H., Ashadi., dan Budi, U. (2013). Studi Komparasi Pembelajaran Cooperatif Metode Teams Games Tournament (TGT) Menggunakan Media Chem-Cards Game Pada Materi Pokok Sistem Koloid Kelas XI Semester Genap SMP Negeri 1 Surakarta Tahun Pembelajaran 2012/2013. Jurnal Pendidikan Kimia, II(4):166-173

Valdez, M., Ferreira, C., \& Barbosa, F. (2013). Teaching circuit theory using a desktop VR system. International Journal of Engineering Pedagogy, 3(4), 5-9. 